\title{
THE EFFECT OF SUPRAPHYSIOLOGICAL DOSES OF VITAMIN E ON PERFORMANCE OF BROILER BREEDERS FLOCK
}

\author{
Mehrdad Yaripour ${ }^{1}$, Mohammad Dadashbeiki², Lorella Giuliotti ${ }^{3}$, Alireza Seidavi1 * \\ ${ }^{1}$ Department of Animal Science, Rasht Branch, Islamic Azad University, Rasht, Iran, ²Department of Veterinary Science, Rasht Branch, \\ Islamic Azad University, Rasht, Iran, ${ }^{3}$ Department of Veterinary Science, University of Pisa-56124, Pisa (PI), Italy \\ ${ }^{*}$ Corresponding author, E-mail: alirezaseidavi@iaurasht.ac.ir
}

\begin{abstract}
The effect of supplementary vitamin E levels on the performance of broiler breeder flocks was studied. A completely randomized design with four treatments $(100,500,1000$, or $1500 \mathrm{lU}$ vitamin E/kg) and three replicates per treatment was used. Each replicate included seven females and one male broiler breeder. Rearing conditions, lighting, temperature, humidity, amount of feed, and the amount of other nutrients in the diet were equal for all treatment groups and according to specifications of the management guide for broiler production. Eggs from each replicate were collected up to six times daily for nineweeks. Every three days, eggs were transferred to a hatchery and their characteristics were determined. The results showed 5-to 15-fold Vitamin $E$ levels over the recommended daily dose had significant negative effects on hatchability and related parameters as well as on herd economic index $(\mathrm{P}<0.05)$.
\end{abstract}

Key words: broiler breeder; hen; tocopherol; reproductive; performance

\section{Introduction}

Vitamin $\mathrm{E}$ has been shown to be an essential vitamin in the diet of poultry (1). Vitamin E, if given in sufficient amount in the poultry diet, can be stored in the body and distributed throughout different tissues and organs (2). In the past, there have been some reports on the vitamin requirements of broiler breeders $(3,4)$. However, genetic, management practice and environmental improvements with broiler breeder flocks has resulted in alteration of their vitamin

Received: 17 March 2017

Accepted for publication: 2 August 2018 requirements (5). Reports about the amount of vitamin requirements for broiler breeder are available $(3,4)$, but the vitamin formulation is no longer adequate for the actual broiler breeder flocks. (1). There are reports on role of vitamins on reproductive performance of broiler breeder hen and roosters $(6,7,8,9,10)$. Based on most important findings it seems that absorption of vitamin $\mathrm{E}$ is facilitated by dietary fat, intestinal bile and pancreatic lipase, and enters the lacteals for transport. The main pathway of its excretion is through defecation. The main role of this vitamin is as an antioxidant, preventing the formation of peroxides. Vitamin $\mathrm{E}$ is protective for vitamin $\mathrm{A}$ and carotenoids in some tissues, e.g. gastrointestinal 
tract. The requirement of vitamin $\mathrm{E}$ increases whenever unsaturated fats are supplemented in poultry diet. Since there are different amounts of unsaturated fats added to commercial breeder broiler diets, the requirement of vitamin $\mathrm{E}$ can change based on fat contents (11). More research is needed in order to determine the requirement of vitamin $\mathrm{E}$ for the broiler breeder hen and rooster under different commercial conditions.

VitaminEwas recently shown to haveantioxidant properties, protecting of cell membranes in both intra- and extracellular spaces (12). In the absence of sufficient vitamin $\mathrm{E}$, breakdown of cell structure occurs, due to the formation of hydroperoxides from unsaturated fatty acids. There is a recent report on the positive effects of extra doses of this vitamin on performance, hatching process, and chick quality in broiler breeder flocks (5). The objective of this experiment was to evaluate the effect of supraphysiological concentration levels of vitamin $\mathrm{E}$ on the reproductive performance of broiler breeder hens.

\section{Materials and methods}

A total of 96 Ross-308 broiler breeders $(84$ hens and 12 roosters), aged between 61 and 69 weeks, were randomly assigned to four treatment groups. The birds were selected at the end of their production cycle, because it was expected that doses of vitamin $\mathrm{E}$ above standard recommendations would improve their performance and inhibit a decline in egg production. The observation period was nine weeks. Hens and roosters weighed, on average, $4.24 \pm 0.1$ and $4.96 \pm 0.1 \mathrm{~kg}$, respectively. Mean body weight for all replicates was the same at the start of the trial. There were three replicates per treatment with seven hens and one rooster.

The experimental facility was surrounded with fences and nets, and the cages $(2.0 \times 1.5 \times 1.0 \mathrm{~m})$ were placed on the ground, in a row, and each cage had one door to the outside. In each cage, there were nests for hens, one for the rooster and a twofloor egg-laying trap. A nipple system, in which water was supplied from a central repository, was created around the cages. In preparation for the trial, the poultry facility was cleaned, rinsed and disinfected. Poultry facilities had thermostatically controlled curtains and cross-ventilation. The lighting schedule consisted 16:8 h light:dark during the period of 61 to 69 weeks of the tests.
The four levels of vitamin E were 100 (Control), 500 (Treatment 2), 1000 (Treatment 3) and 1500 (Treatment 4) IU vitamin E/ kg diet. 100 IU vitamin $\mathrm{E} / \mathrm{kg}$ in the diet represents the recommended concentration of vitamin $\mathrm{E}$. The effect of the doses was evaluated for 63 days. A standard broiler breeder's diet $(2800 \mathrm{kcal}$ of $\mathrm{ME} / \mathrm{kg}$ and $14.5 \% \mathrm{CP}$ for female and $2700 \mathrm{kcal}$ of $\mathrm{ME} / \mathrm{kg}$ and $13.5 \% \mathrm{CP}$ for male) was fed to meet or exceed broiler breeder nutrient requirements (13). Feed was provided ad libitum and feed intake calculated weekly by difference between the quantities fed and left over. The ingredient composition and the energy content of the diet were kept similar for all the groups (Table 1).

Weekly egg production, egg counts, and egg weights per pen were recorded. Eggs were manually collected, weighted, and incubated at a commercial hatchery. At the hatchery, they were candled by a trained operator for eggshell defects and screened at day 12 for unhatched eggs. Unhatched and hatched eggs were sorted out, counted and weighted (hatchable produced egg number, hatchable total egg weight, hatchable egg weight average, dirty egg number, hatchable total egg weight at transfer incubator to hatcher, hatchable egg weight average at transfer incubator to hatcher, egg loss weight).

At the end of incubation, the number of live healthy chicks was counted ("chicks produced") and eggs weighed (total chick weight and mean chick weight). "Chick yield" was the percentage of initial eggs from which live chicks hatched (number of eggs hatched/number of initial eggs). "Percent hatchability: was calculated from eggs yielding live chicks (number of eggs hatched/ number of fertile eggs). "Economic index" was calculated as sum of the weekly chick number and half of the dirty eggs.

Statistical analysis was performed with SPSS (14). For statistical analysis, the replicate chicken pen was considered as the experimental unit. Data were subjected to a mixed linear model, with replicates as random factors, treatment as fixed factors and performance parameters as dependent variables. A completely randomized design, with four treatments and three replicates per treatment, was used. Alternatively, Kruskall-Wallis test was used. If both tests were significant, subsequent Pairwise testing was conducted using Bonferroni's method. Data between $0-0.5$, or percentages between $0-30$ were transformed into $\mathrm{x}^{0.5}+0.5$. 


\section{Results}

Neither hen nor rooster weights differed significantly among the treatment groups at the beginning and at the end of the trial. Hens produced 1.82 dirty eggs / hen in the Control group, whereas in Treatment 4 only 0.81 dirty eggs/hen were produced ( $p=0.013$ ) (Table 2$)$. The percentage of egg loss weight differed significantly $(p=0.052)$ between the Control group and Treatment 4 . Hens produced 16.71 chicks/hen in the Control group, whereas in Treatment 4 only 7.05 chicks / hen were produced $(\mathrm{p}=0.023)$. Hens in the Control group produced $1103.81 \mathrm{~g}$ total chick weight, which was significantly superior $(\mathrm{p}=0.003)$ compared to $756.21 \mathrm{~g}, 783.76 \mathrm{~g}$ and $387.28 \mathrm{~g}$ in Treatments 2 , 3 , and 4 respectively. The hatchability percentage was significantly lower in Treatment 4 (35.58\%) compared to the other groups. The economical index confirmed the significantly inferior results $(p=0.008)$ reported for Treatment $4(7.45)$.

Other traits were not significantly affected by the treatments. Briefly, hens in Treatment 3 had the greatest number hatchable eggs, hatchable total egg weight, hatchable total egg weight at transfer from incubator to hatchery,

Table 1: Experimental diets fed to broiler breeder hens and roosters

\begin{tabular}{|c|c|c|}
\hline & Hens & Roosters \\
\hline \multicolumn{3}{|l|}{ Ingredients, \% } \\
\hline Maize & 69.64 & 66 \\
\hline Soybean meal (44\% protein) & 18 & 11 \\
\hline Wheat bran & 2.47 & 18.37 \\
\hline Vitamin and Mineral premix & 0.5 & 0.5 \\
\hline Calcium carbonate & 6.5 & 1.5 \\
\hline Oysters shell & 0.5 & 0.5 \\
\hline Dicalcium phosphate & 1.4 & 1.4 \\
\hline DL-methionine & 0.4 & 0.08 \\
\hline L-lysine HCL & 0.01 & 0.07 \\
\hline Salt & 0.2 & 0.2 \\
\hline Sodium bicarbonate & 0.15 & 0.15 \\
\hline Natuzyme P & 0.03 & 0.03 \\
\hline Toxin binder & 0.1 & 0.1 \\
\hline Formycine Gold & 0.1 & 0.1 \\
\hline \multicolumn{3}{|l|}{ Calculated analysis } \\
\hline Metabolizable energy, $\mathrm{kcal} \mathrm{kg}^{-1}$ & 2800 & 2700 \\
\hline Crude protein, \% & 14.0 & 13.5 \\
\hline Calcium, \% & 3.0 & 1.1 \\
\hline Available Phosphorus, \% & 0.4 & 0.4 \\
\hline Sodium, \% & 0.16 & 0.16 \\
\hline Chloride, \% & 0.16 & 0.18 \\
\hline Lysine, \% & 0.6 & 0.6 \\
\hline Methionine, \% & 0.033 & 0.3 \\
\hline Ether extract, \% & 2.9 & 3.15 \\
\hline Fibre, $\%$ & 2.9 & 4.2 \\
\hline Linoleic acid, \% & 1.65 & 1.8 \\
\hline
\end{tabular}

${ }^{1}$ Supplied per kilogram of feed - Vitamin A: $12500 \mathrm{IU}$; vitamin $\mathrm{D}_{3}$ : $1250 \mathrm{IU}$; vitamin E: $18 \mathrm{IU}$; vitamin $\mathrm{K}_{3}: 3.7 \mathrm{mg}$; thiamine: $1.8 \mathrm{mg}$; riboflavin: 6.6 mg; calcium pantothenate: $10 \mathrm{mg}$; niacin: $37.5 \mathrm{mg}$; pyridoxine: $32.5 \mathrm{mg}$; vitamin B12: $2.5 \mathrm{mg}$; Mn: $50 \mathrm{mg}$; $\mathrm{Zn}$ : $37.5 \mathrm{mg}$; Fe: $25 \mathrm{mg}$; Cu: $7.5 \mathrm{mg}$. 


\begin{tabular}{|c|c|c|c|c|c|c|}
\hline 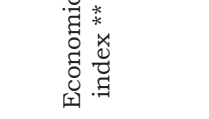 & 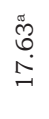 & 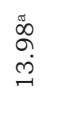 & 䍃 & $\stackrel{\text { i⿱ }}{\stackrel{1}{r}}$ & 章 & $\begin{array}{l}\infty \\
\stackrel{0}{0} \\
0\end{array}$ \\
\hline 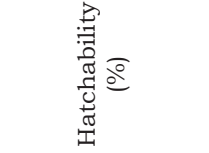 & $\begin{array}{l}\text { 悤 } \\
\stackrel{\circ}{\circ}\end{array}$ & 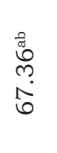 & 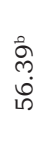 & 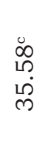 & 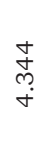 & $\begin{array}{l}\overrightarrow{8} \\
\circ\end{array}$ \\
\hline 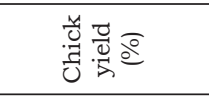 & 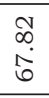 & $\begin{array}{l}0 \\
\stackrel{\overbrace{}}{\hat{0}} \\
.\end{array}$ & $\begin{array}{l}0 \\
0 \\
0 \\
0\end{array}$ & $\begin{array}{l}\stackrel{0}{0} \\
\hat{\overbrace{}}\end{array}$ & \begin{tabular}{c}
0 \\
\multirow{1}{*}{} \\
0 \\
\end{tabular} & $\begin{array}{l}\infty \\
\text { în } \\
0 \\
0 \\
0\end{array}$ \\
\hline 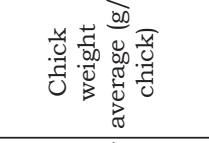 & 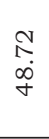 & $\begin{array}{l}\stackrel{L}{0} \\
\stackrel{\infty}{+}\end{array}$ & $\begin{array}{l}\infty \\
\infty \\
\infty \\
\infty\end{array}$ & $\begin{array}{l}\vec{i} \\
\stackrel{+}{r}\end{array}$ & $\begin{array}{l}0 \\
\stackrel{0}{0} \\
\vdots \\
0\end{array}$ & $\begin{array}{l}L^{2} \\
\infty \\
0 \\
0\end{array}$ \\
\hline 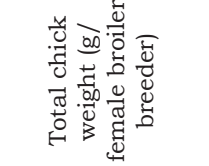 & 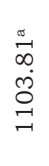 & 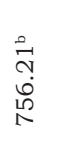 & 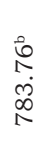 & 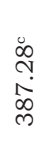 & $\begin{array}{l}\infty \\
\infty \\
\rightarrow-1 \\
\infty \\
\infty\end{array}$ & $\stackrel{\infty}{\circ}$ \\
\hline 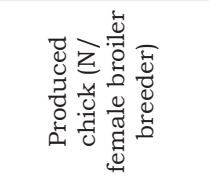 & 离 & 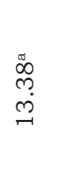 & 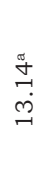 & 号 & 卓 & 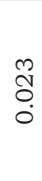 \\
\hline  & 占 & $\begin{array}{l}\text { o̊ } \\
\text { : } \\
0\end{array}$ & 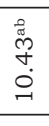 & 号 & 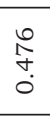 & $\begin{array}{l}\text { Î } \\
\text { है } \\
0\end{array}$ \\
\hline 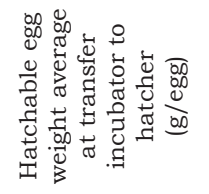 & 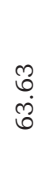 & \begin{tabular}{l}
$\infty$ \\
\multirow{0}{+}{} \\
$\dot{0}$
\end{tabular} & $\begin{array}{l}\stackrel{M}{\hat{i}} \\
\text { ô }\end{array}$ & $\begin{array}{l}\overrightarrow{7} \\
\dot{+}\end{array}$ & 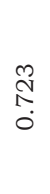 & $\begin{array}{l}\text { के } \\
\text { के }\end{array}$ \\
\hline 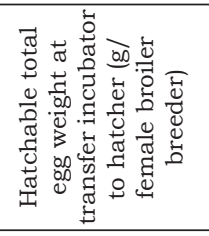 & 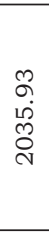 & 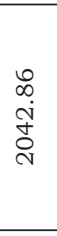 & 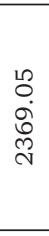 & $\begin{array}{l}\text { ò } \\
\text { ò } \\
\text { ते }\end{array}$ & 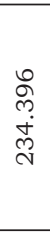 & 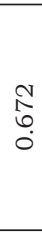 \\
\hline  & 范 & $\stackrel{\circ}{\stackrel{\circ}{ت}}$ & 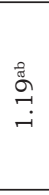 & $\begin{array}{l}0 \\
\infty \\
0 \\
0\end{array}$ & \ั. & $\begin{array}{l}m \\
\stackrel{0}{0}\end{array}$ \\
\hline 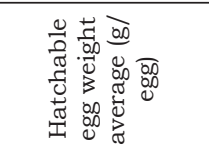 & $\begin{array}{l}\vec{\infty} \\
\vec{i}\end{array}$ & $\begin{array}{l}\hat{N} \\
\stackrel{N}{N}\end{array}$ & $\begin{array}{l}\dot{1} \\
\dot{0} \\
\dot{1}\end{array}$ & 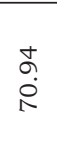 & 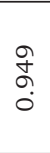 & 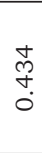 \\
\hline 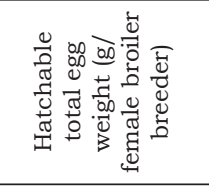 & $\begin{array}{l}\infty \\
0 \\
0 \\
\stackrel{\sim}{0} \\
\text { N }\end{array}$ & $\begin{array}{l}\hat{1} \\
\infty \\
\infty \\
N \\
\sigma\end{array}$ & $\begin{array}{l}\hat{L} \\
\dot{+} \\
\vec{j}\end{array}$ & 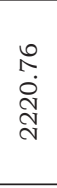 & 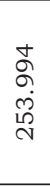 & $\stackrel{\stackrel{P}{+}}{\stackrel{0}{0}}$ \\
\hline 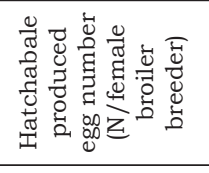 & $\begin{array}{l}\stackrel{\circ}{\leftrightarrow} \\
\stackrel{+}{N}\end{array}$ & $\stackrel{\infty}{\stackrel{\infty}{\leftrightarrow}} \stackrel{i}{i}$ & $\begin{array}{l}\stackrel{2}{2} \\
\text { ה̀ }\end{array}$ & 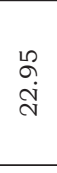 & $\begin{array}{l}\stackrel{P}{N} \\
\text { ì } \\
\text { in }\end{array}$ & $\begin{array}{l}\infty \\
\infty \\
\infty \\
0\end{array}$ \\
\hline & $\stackrel{\circ}{\circ}$ & 오․ & 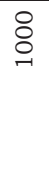 & $\begin{array}{l}8 \\
\text { : } \\
\end{array}$ & 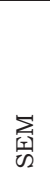 & 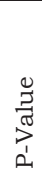 \\
\hline
\end{tabular}


and chick yield compared to other treatments, but these were not significantly different from the other treatments. Hens in Treatment 2 had only a numerically greater mean hatchable egg weight and hatchable egg weight at transfer from incubator to egg hatcher, compared to other treatments. Finally, the Control group had the highest chick weight average compared to other treatments, but again the difference was not statistically significant (Table 2).

\section{Discussion}

Next to the cost of feeding, the major benchmark for a broiler breeding farm is the number of chicks produced per hen. Furthermore, these chicks must be of optimal weight for successful future meat production. Thus, presuming management conditions are optimal, the total number of chicks delivered per hen for rearing and the total weights of these of chicks per hen are two important parameters. Hens supplemented with a normal level of vitamin $\mathrm{E}$ in their ration (control) produced 16.71 chicks per hen, which was better than that of hens fed with overdoses. Furthermore, the total weight of all chicks produced per hen of the Control group was significantly more that of the three treatment groups and resulted in a better economic index. Since mean chick weight was around 48 grams, the high numbers of chicks produced in the control group was the major success factor.

The numbers of hatched chicks per hen depend on the numbers of eggs laid, as well as on the numbers of eggs that are fertilized by the roosters. Thus, health is important for both parents.

One explanation for the increased production of chicks per hen could be due to increased egg production per hen, but the number of hatchable eggs per treatment group was not significantly different. Thus, in our studies, egg production was not significantly affected by excessive vitamin $\mathrm{E}$ level in the feed.

More important for hatchability is the quality of the hatchable and fertilized eggs per hen. It appears that above normal doses of vitamin $\mathrm{E}$ did not affect egg production per se, but dramatically decreased hatchability.

Other research did not find positive effects of high levels of vitamin $\mathrm{E}$ supplementation on chick yield and weight in laying breeders (3). Yet another study showed that a deficiency of vitamin E lead to impairment of the reproductive organs, such as degeneration of the seminiferous tubules, degenerative spermatogonia and testicular damage (15). Vitamin $\mathrm{E}$ as a free radical scavenger can prevent the oxidation of readily oxidized substances. The potential of vitamin $\mathrm{E}$ to act as a lipid-based radical chain-breaking agent and protect against free-radical attack is considered fundamental to its effects in biological systems such as broiler breeders (16). Apparently, the expected beneficial antioxidant activity of larger than normal doses of vitamin $\mathrm{E}$ compromises the development of the chicken embryo, resulting in poor hatchability. Negative effects of "hyperdoses" of vitamin $\mathrm{E}$ have been linked to impairment of absorption of vitamins A and D3. Furthermore, weak bone calcification was observed when birds received "hyperdoses" of vitamin $\mathrm{E}$, and body weight decreased after an increase of dietary vitamin $\mathrm{E}$ (17). At "hyperdoses" of vitamin $\mathrm{E}$, there was decreased pigmentation of the shanks, feet and beak and waxy feathers. There are similar studies about positive effects of optimum doses and negative effects of "hyperdoses" of vitamin $\mathrm{E}$ $(18,19,20,21,22)$.

Our results may be explained by findings of meta-analyses of clinical studies in man that showed that supplementation of vitamin $\mathrm{E}$ as antioxidants did not result in the presumed health benefit, but was rather associated with increased mortality (22). The conclusion of this trial is that the vitamin E levels of $100 \mathrm{IU} / \mathrm{kg}$, as currently advised in broiler breeder production, should not be increased.

\section{Acknowledgments}

The work was supported by Financial Rasht Branch, Islamic Azad University, Rasht, Iran (Grant number 17.16.4.8774).

\section{References}

1. Leeson S. Vitamin requirements: is there basis for re-evaluating dietary specifications? World Poultry Sci J 2007; 63: 255-66.

2. Khan RU, Naz S, Nikousefat Z, et al. Effect of vitamin $\mathrm{E}$ in heat-stressed poultry. World's Poult Sci J 2011; 6: 469-78.

3. Hossain SM, Barreto SL, Bertechini AG, 
Rios AM, Silva CG. Influence of dietary Vitamin $\mathrm{E}$ level on egg production of broiler breeders, and on the growth and immune response of progeny in comparison with the progeny from eggs injected with Vitamin E. Anim Feed Sci Technol 1998; 73: 307-17.

4. Calini F, Sirri F. Breeder nutrition and offspring performance. Rev Bras Cienc Avic 2007; 9: $77-83$.

5. Urso URA, Dahlke F, Maiorka A, et al. Vitamin $\mathrm{E}$ and selenium in broiler breeder diets: effect on live performance, hatching process, and chick quality. Poult Sci 2015; 94: 976-83.

6. Khan RU, Javed I, Muhammad F. Effects of vitamins, probiotics, and protein level on semen traits and some seminal plasma macro-and micro minerals of male broiler breeders after zinc-induced molting. Biol Trace Elem Res 2012; 148: 44-52.

7. Jena BP, Panda N, Patra RC, Mishra PK, Behera NC, Panigrahi B. Supplementation of vitamin $\mathrm{E}$ and $\mathrm{C}$ reduces oxidative stress in broiler breeder hens during summer. Food Nutr Sci 2013; 4: 33-7.

8. Zaghari M, Sedaghat V, Shivazad M. Effect of vitamin $\mathrm{E}$ on reproductive performance of heavy broiler breeder hens. J Appl Poultry Res 2013; 22: 808-13.

9. Khan RU, Javed I, Muhammad F. Supplementation of dietary vitamins, protein and probiotics on semen traits and immunohistochemical study of pituitary hormones in zinc-induced molted broiler breeders. Acta Histochem 2013; 115: 698-704.

10. Khan RU, Rahman ZU, Javed I, Muhammad F. Effect of vitamins, probiotics and protein level on semen traits and seminal plasma biochemical parameters of post-moult male broiler breeders. Br Poultry Sci 2013; 54: 120-9.

11. Raederstorff D, Wyss A, Calder PC, Weber $\mathrm{P}$, Eggersdorfer $\mathrm{M}$. Vitamin $\mathrm{E}$ function and requirements in relation to PUFA. Br J Nutr 2015; 114: 1113-22.
12. Li X, Dong Z, Zhang F, Dong J, Zhang Y. Vitamin E slows down the progression of osteoarthritis: review. Exp Ther Med 2016; 12: 18-22.

13. Ross 308 Broiler: Nutrition specification. Newbridge: Aviagen, Scotland. http://www. natchix.co.za/pdf/nutrition_specifications.pdf (May 25, 2009)

14. SPSS. SPSS Base 7.5 for Windows. Chicago, IL : SPSS, 1997.

15. Wilson MJ, Kaye D, Smith WE, et al. Effect of vitamin E deficiency on the growth and secretory function of the rat prostatic complex. Exp Mol Pathol 2003; 74: 267-75.

16. Azzi A, Stocker A. Vitamin E: non-antioxidant roles. Prog Lipid Res 2000; 39: 231-55.

17. Nockels CF, Menge DL, Kienholz EW. Effect of excessive dietary vitamin $\mathrm{E}$ on the chick. Poult Sci 1976; 55: 649-52.

18. Khan RU, Rahman ZU, Javed I, Muhammad F. Effect of vitamins, protein level and probiotics on immune response of molted male broiler breeders. J Anim Morphol Phys 2014; 98: 620-27.

19. Khan RU, Rahman Z, Javed I, Muhammad F. Serum antioxidants and trace minerals as influenced by vitamins, probiotics and proteins in broiler breeders. J Appl Anim Res 2014; 42: 24955.

20. Surai PF, Fisinin VI, Karadas F. Antioxidant systems in chick embryo development. Part 1. Vitamin E, carotenoids and selenium. Anim Nutr 2016; 2: 1-11.

21. Vrolijk MF, Opperhuizen A, Jansen EH, et al. The shifting perception on antioxidants: the case of vitamin $\mathrm{E}$ and $\beta$-carotene. Redox Biol 2015; 4: 272-8.

22. Min Y, Sun T, Niu Z, et al. Vitamin C and vitamin $\mathrm{E}$ supplementation alleviates oxidative stress induced by dexamethasone and improves fertility of breeder roosters. Anim Rep Sci 2016; 171: 1-6. 


\title{
UČINEK SUPRAFIZIOLOŠKIH ODMERKOV VITAMINA E NA PRIRAŠČANJE VZREJNIH BROJLERJSKIH JAT
}

\author{
M. Yaripour, M. Dadashbeiki, L. Giuliotti, A. Seidavi
}

Povzetek: V študiji smo raziskovali učinek dodajanja vitamina E na hitrost prirasta v vzrejnih brojlerskih jatah. Študija je bila zasnovana naključno s štirimi koncentracijami dodatka (100,500, 1000 ali 1500 i.e. vitamina E/kg telesne mase) in tremi ponovitvami tretiranja za vsako koncentracijo dodanega vitamina E. Vsaka ponovitev je vključevala sedem samic in enega brojlerskega samca. Pogoji reje, razsvetljava, temperatura, vlaga, količina krme in količina drugih hranilnih snovi v prehrani so bili enaki za vse poskusne skupine in v skladu s specifikacijami reje pitovnih piščancev. Jajca iz vsake ponovitve tretiranj po skupinah so bila zbrana do šestkrat dnevno devet tednov. Vsake tri dni so bila jajca prenesena v valilnico, kjer smo določili njihove značilnosti. Rezultati so pokazali da so imele 5- do 15-kratne vrednosti vitamina E nad priporočenim dnevnim odmerkom značilno negativne učinke na sposobnost valjenja in sorodnih parametrov, kakor tudi na na čredni gospodarski indeks $(P<0,05)$.

Ključne besede: brojlerji; kokoš; vitamin E; razmnoževanje 